\title{
CHANGES IN THE ROLE OF THE POLITICAL PARTIES AND INSTITUTIONS IN THE POST-DEMOCRACY
}

\begin{abstract}
The article discusses the changes in the role of the political parties and institutions in the modern post-democratic societies. The goal of this paper is to present and analyze the models of establishing and functioning of the political parties and institutions in the post-democratic era, their relation with the contemporary political realities in Bulgaria and in the countries of the European Community. The main approach in the study and the analysis of the problems posed to the political parties is sociological, combined with the interdisciplinary one. The models of the political parties and institutions are traced and analyzed through the eyes of the modern political science. Outlined is the fact that there is a real danger political parties to become dependent on corporate elites and the widespread political populism. Real conditions and approaches for overcoming these shortcomings are indicated.
\end{abstract}

Keywords: political parties; political institutions; models of political parties; leadership cores

The problems concerning the role and significance of the political parties in the postdemocracy are the subject of research by Colin Crouch in his two publications "PostDemocracy" (2012) and "Neoliberalism and Social Democracy - the Fight Continues" (2019). In the first monographic study, the author applies an original approach in defining the nature of the relation between the parties and their wider electorate. This democratic model of research, also known as concentric circles model, Colin Crouch applies to studying the parties. What is the nature and the specifics of this model? It mainly relies on a series of interconnected concentric circles, which should clarify the complex relation between the individual parties and their wider electorate. The distinguishing feature of these circles is that they have an increasing size and are connected in a special way. According to Colin Crouch,

"the smallest circle is the core of leaders, plus their advisers; then come the parliamentary representatives; then the active members - people who spend a lot of time working for the party: local government representatives, local activists, as well as paid apparatchiks; followed by ordinary members who do little for the party but want to be symbolically

1 mitkodimitrov47@abv.bg 
associated with it, help on specific occasions and pay regular membership fees; then come supporters or loyal voters who essentially do nothing for the party except vote for it in the elections; and finally, the largest circle is the broad target electorate that the party seeks to persuade to vote for it" (Giddens, 1998, p. 80).

This definition of the party model of circles of different sizes and growth should become a table book for those ambitious politicians who after leaving the leadership positions in a party or state institution most often are forced to take actions to establish a new party under their personal leadership. The current political life in Bulgaria is full of such examples. For instance, after the end of Mr. Parvanov's presidential term, he established a new party (ABV), which did not succeed to confirm itself in the country's political life. There are similar examples among other political powers in the country. The sociological analysis of this model allows us to draw several significant conclusions.

First, in a democratic party, the circles are concentric in nature and reflect the direction of movement between their participants. For example, leaders are usually elected by activists, who in turn are elected by party members. The specific here is the fact that the party members themselves are representatives of different parts of the electorate, whose interests the party seeks to represent.

Second, the main function of the concentric circles, especially the intermediate ones, is to create appropriate conditions for building strong relations between the political leaders and the electorate as they pass through the various levels in the party. According to Colin Crouch, this model is particularly important for the "self-perception of the workers' parties, and for the regional and separatist ones, as well as for some that are Christian Democratic and fascist ones. They emerge outside the parliament as social movements and then develop a parliamentary wing. But in the $20^{\text {th }}$ century, the social roots have become increasingly important for the old parties too, emerged among the political elite, and later, when the era of democracy have unexpectedly caught up with them, they have rushed to fabricate a national movement" (Giddens, 1998, p. 80-81). Examples in this direction can be cited among the modern European elites, as in Bulgaria as well. For example, Movement for Rights and Freedoms, "Ataka", Patriotic Front, and others, meet these conditions in Bulgaria. Pointing out the ironic nature of the emergence of these "party movements", Colin Crouch notes that with the rise of the post-democracy, their previous appearance, namely the model of movement, becomes more realistic. Special attention deserves the conclusion of the mentioned author that, like any ideal, such a model of concentric circles, strictly outlining the rules of movement between these circles, practically have never existed, but it is still instructive to observe this process.

The rules of the game in politics are not the only ones and are not created for eternity. That is why, in the study of these processes and problems, should be taken into account those cases of tension, when the party leaders have doubts and do not feel the real support of the "loyal electorate". For the political analysts, these are particularly important signals that, if not taken into account, a party's political influence will decline and the reasons for this should be investigated. Sociology researchers come to the rescue here. They, with the help of public opinion polls, can orient the leaders of the respective party on the nature of the reasons and directions in which they should be sought.

Continuing his analysis of the challenges that the post-democracy poses to the political parties, Colin Crouch warns of the following fact concerning the consequences for 
the concentric model. "A further change was the strong expansion of the circles of advisers and lobbyists around the leaders. Although three groups can be distinguished - leaders, advisers, lobbyists - in practice people move between these positions, together constituting the special occupation of politics" (Giddens, 1998, p. 82). With the emergence of these three groups, the very core of the party changes, as well as the other party circles, which acquire an elliptical character. A more special place in the structure of the party is occupied by the "pure professionals", who may not be party members, but are hired to perform a strictly defined job. The goals of these groups usually overlap with the goals of lobbyists who work also for certain companies and who have certain interests in the government business. They all have the ultimate goal of establishing closer contacts with the politicians. In this vicious circle, there are certain conditions for scandals and participation in corruption schemes. That is why all parties are vulnerable and may experience the consequences of such, sometimes fatal, conflicts and tensions. As Colin Crouch notes, "especially in a period of profound class change, they can become unmanageable... And the result of using experts was that the leadership structure moved even further from the party circles to the ellipse" (Giddens, 1998, p. 83-84). In fact, this ellipse creates new conditions for interaction with the party leaders. The expertise and knowledge of the ellipse are much more valuable, more useful than the "amateur enthusiasm" of the party activists. That is how, if we trust the current trends, we will see the new face of the $21^{\text {st }}$ century party.

“This party, says Colin Crouch, will encompass a self-replicating domestic elite, distant from the mass movements as its base, but nestled entirely in several corporations, which subcontract the services on studying the public opinion... the companies seeking political influence in turn are favored by the party - when it is in power" (Giddens, 1998, p. 84).

In a similar way, a right-wing party called Forza Italia was formed, which, after corruption scandals in the early 1990s among the Christian Democratic and Socialist parties, cleared the way for the power of entrepreneur Silvio Berlusconi. This type of a party is a kind of a network of companies, and its success is mainly due to the personal qualities of its leader. For such parties the need for money is huge, and the election campaigns become more and more expensive. Under these conditions, the need for wealthy donors grows, and the opportunities to raise funds in another legal way become more and more limited. The "kingdom of chaos" comes, where most political parties turn to corruption practices that discredit their image, and by the time they realize it, they have already lost the support of their members and unions and have become heavily dependent on the corporations. According to Colin Crouch, a strange paradox appears, in which the new ellipse that includes the movement from the leadership to its advisers and outside lobbies, contains elements from the pre-democracy and the post-democratic period (Giddens, 1998, pp. 86-87). This is how the image and structure of the post-democratic political parties are built.

Here I will focus mainly on some of my analyses and conclusions on the raised questions about the parties, made in my monograph "Power and Politics" (2017). One of the goals of that study was to use the sociological approach to look at the party as a political organization in the context of the overall democratic process. Achieving this goal required to trace the historical conditions and the time during which political parties were established. In this sense, my study began with analyzing the results of the studies and analyses of Max Weber, presented in the publication "The Scientist and the Politician" (Weber, 1993). 
Analyzing in depth the conditions in which "professional politicians" are created, Max Weber points out the reasons for their existence. He notes: "One can engage in "politics", i.e. seek to influence the distribution of power between the political formations and within them, either just in some cases, or as a politician for whom this is a side or main profession" (Weber, 1993, p. 52). Explaining how professional politicians differ from the ordinary voters, Max Weber concludes that there are only two ways for a person to turn politics into his profession: "he should either live by the politics or live for the politics". And the one does not exclude the other (Weber, 1993, p. 53). It is a typical definition that explains the specifics of the time in which Max Weber has lived, namely the time in the Western politics before the emergence of the parties. His reflections and analyses have answers to the questions: Who are the people interested in the political life? How are the candidates for the elections selected? How are votes won? These answers sound relevant also today from the distance of the time in which Max Weber has lived. From a methodological point of view, I have referred to the Bulgarian sociologists, who pay special attention to revealing the nature of the parties in today's representative democracy. In the study of Georgy Fotev, revealing the nature of the parties relates to the task of the modern democracy, which, according to him, is called

"to establish social order on the basis of disagreements and these disagreements would form an unimaginable cacophony, they would result in an unimaginable chaos without mechanisms, tracing the way for the social order, maintaining order, including its change and development in a democratic way" (Fotev, 2001, p. 323).

With the outlined disagreement in the opinions, established is a group of those who are unanimous on certain political issues, who unite in the political party. According to Fotev, this party is a "specific association" in the democratic society. The other comparison that the author uses for the party is as a "laboratory", i.e. "a school of party-political life", where the party activist acquires specific political knowledge and political competence, can develop his talents as a political leader, and observed, first by his party members, and proven his qualities to them and the political society, he could have a successful party and political career (Fotev, 2001, p. 325).

Mincho Semov has a different view of the nature and ways of organizing the parties. He seeks for the reasons for the emergence of the political organizations in the very nature and essence of the public life organized within the state. This author draws the attention to an important fact, namely the existence of centers of power that have a certain resource of means to influence the political life in the society. The establishment of the political party as an organization is associated with a clear set goal, namely to conquer the centers of power in the society. This statement, defended by Mincho Semov, is in the orbit of the thesis of the power, defended by Max Weber, i.e. the party is established to participate in the exercise of power. Any other thesis that denies this goal in the establishment of a party would be an expression of a hypocritical politicking and populism. According to Mincho Semov,

"the party is an organized association of people with a community of interests, ideas and views. The classic goal is: these interests, ideas and views to be imposed on the whole community (society, state), by taking the power. A temporary goal of the political party can be the preservation of certain values, preservation and transfer "of the fire", etc. (Semov, 2000, p. 387). 
The discussion on the problems concerning the nature, structure and place of the political parties in the political system of the society continues also today in the sociological literature. I will finish this discussion with my thesis about the nature of the political party, its structure and functions. Before presenting my definition of a political party, I will make two clarifications, namely that I consider the party as a means of participating in power, and second, that the party is one of the "main instruments for political competition" (Jacques Chevallier). In this sense, my definition of the "party" is influenced by the theses of the mentioned author.

In my opinion, a political party is a two-faced political enterprise (not an economic one), something like the "two-faced Janus". One face is turned inwards to the members who represent parts of social groups and communities that have common interests and goals related to the party's participation in the power, having voluntarily agreed and recognized the right of the party leadership to control their actions. The other face is turned outwards, to the representatives of the civil society, the trade unions and other organizations and political parties, which have the same goal - participation in the power and distribution of the benefits from it. The first face turned inwards provides discipline and control over the interrelations between the various hierarchical levels, while the second face turned outwards determines the conditions for cooperation with the other political parties, the civil society, trade unions and parts of other organizations. The main concern of this face is with whom, when and how to form coalitions and other contractual relations in order to win participation in the power. This definition of mine is set as a methodological condition in the current study, where I will briefly focus on the discussion concerning the functions of the political parties. Bulgarian and foreign authors from the political science circles have definitely a more active participation in this discussion. In this sense, I will note also the view of the mentioned French researcher Jacques Chevallier. The original in his view is that in his monograph "Institutions Politiques" (2010), analyzing the functions of the political parties, he starts from the thesis that the functions of the parties are ambiguous, both overt and covert. To the overt functions he refers three types:

"creating public opinion by presenting to the voters a set of opinions (program function) and constantly bringing life to the public debate; the recruitment of political staff (selection function) by nominating candidates in the elections and for responsible management positions; coordination and control of the activities of the elected (framing function) through the parliamentary groups. But the parties, he states, also take covert functions: political socialization (political education and vote structuring), social integration (suggestion of beliefs) and social mobility (a "tribunes" function that makes them provide protection and representation to certain social strata that have gone to marginalization)" (Chevallier, 2010, p. 107).

The comparison of the theses of the already mentioned sociologists and political scientists bears a sign of "overlap" in the definition of the political parties and their functions. Taking into account this fact, the political scientist Georgi Manolov defines the following "most significant" functions of the parties. He groups these functions into

"two key groups: representative - functions exercised to the civil society (articulation and aggregation of the public interests; institutionalization of the social conflicts, relation of the civil society and the state; formation of the public opinion...), and institutional functions exercised to the public administration (7 in total)" (Manolov, 2016, p. 244). 
This author's thesis on the party functions is discussed in more detail in my monograph "Power and Politics" (2017), so here I will just state that I share the author's opinion on the stabilizing function of the parties, which is due to their ability to institutionalize the social conflicts. From the standpoint of my definition of the party, I will only add that in addition to external conflicts related to civil and other disturbances, the party can regulate also internal conflicts that have risen between the different hierarchical levels, different groups of members who do not share certain decisions of the leadership concerning the running of organizational and structural reforms, the rules for participation in parliamentary groups, the right to participate in parliamentary elections and others. Most of the mentioned types of conflicts have risen during the BSP plenum concerning the election of a new party chairman. The battle continues with strong force between the old party members who have held certain leadership positions, such as the leader of this group, the leader of the Plovdiv party organization and other supporters of his, and the entourage of the current party leader. The result of this battle will be clear in the autumn of 2020, when the party congress is scheduled. The existence of certain conflicts, such as the mentioned ones related to the renewal of the leadership of a party, are not so dangerous and can be defined even less as unhealthy for the party. On the contrary, my thesis is that conflicts of this kind act healthy and testify to the healing of the respective party organism, as long as they are systematically monitored and look for ways to overcome the differences that the conflicts have caused.

In conclusion, I will note that the number and nature of the functions of a political party depend on its type. In this sense, I think that the development of a typology of the parties is important for a more in-depth study of the nature and character of the political parties. In my already mentioned study "Power and Politics" (2017), I have analyzed the existing typologies in the Bulgarian and foreign literature and therefore here I will not discuss in detail the problems in the development of the respective typologies of the parties.

An important place in my study is set for the political institutions as one of the main elements of the political system of the power in the conditions of the post-democracy and the overall political process. The term "institution", as stated by Jacques Chevallier, has originated in France in 1954 in connection with the reform of the legal education in the textbooks on constitutional law and is one of the successful attempts of the political science in France to create conditions for "crossing the borders" of the legal approach.

A little later, in 1955, the training courses of Georges Burdeau and Maurice Duverger have undergone major changes in favor of affirming the need to take into account the right of existence of the "political institutions". In this way conditions and real preconditions are created, as Jacques Chevallier notes,

"the teachers of constitutional law to not only follow the regulations and bodies provided by the constitution, but also to be interested in the political reality, the conditions for the application of the constitutional norms by the groups influencing the exercise of the political power, especially of the parties" (Chevalier, 2010, p. 9).

Maurice Duverger, who in 1951 has published the monograph "Political Parties", also has a certain merit for legitimizing the term "political institutions". His study confirms the term "party system", which is increasingly associated with the political regimes. However, 
Jacques Chevallier notes that ever since its creation the phrase "political institutions" contains certain ambiguities. With the development of the political science, the term "political institutions" occupies a well-deserved place in the political science research and, as noted by the mentioned author, following the logics of institutionalization of the "political institutions", the notion that the political institutions are only one variety of the social institutions confirms (Dimitrov, 2017, p. 91). In the Bulgarian sociological literature, attention deserves the definition of a social institution given by Stoyan Mihailov in his monographic study "Sociological System" (2010). According to him:

"The social institution is established to organize, channel, direct and control the activities of the people. It follows the division of public labor. It is differentiated according to the relatively specified types of human activity. That is why the social institution is of different types - production, management, educational, scientific, commercial, sports, church, communication, political one, etc. (Mihailov, 2010, p. 70).

In other words, here the author emphasizes on the fact that each institution belongs to one of the main spheres of the society or its main area as part of the sociological system of the society. The already mentioned French researcher Jacques Chevallier points out that the studies of the political institutions are already largely aware of the fact that these institutions are essentially a kind of "support structure" of the order in the society. That is why, Jacques Chevallier notes, "institutions should be understood as social facts that are permanently inscribed in the time, resemble "objective" or "natural" reality and live as such through the individuals" (Chevallier, 2010, p. 34).

In our political science literature there are two essential definitions of the political institutions by Bulgarian authors. According to Antoniy Todorov, "the political institutions should be considered as a system of regulations and norms that ensures a certain social and political order" (Todorov, 2012, p. 78). But as the author points out, in everyday life there are institutions that include state authorities and their units such as government, parliament, president, court, police, army and others. The other definition of political institutions belongs to the political scientist Georgi Karasimeonov, who states: "In a broader sense, the institutions include the so-called intermediary institutions between the citizens and the state such as the political parties and the other civil society organizations. Sometimes these institutions are called civic institutions" (Todorov, 2012, p. 79). What is important in the study of the political institutions, as Mincho Semov reminds us, is that their public character should be distinguished from the private life.

In my monographic study "Power and Politics" (2017) I have paid special attention to the other types of political institutions such as: state, parliament, government, judiciary, which make the political connection between the political system and its institutions within the overall political process. That is why I will not discuss here their nature and way of functioning, but rather some of the specifics of the political institutions such as the state. According to Colin Crouch's figurative expression, in the context of the post-democracy, "the state becomes a kind of "institutional idiot" whose actions are anticipated and neutralized, as believed by the ideologists of the market economy of omniscient markets" (Crouch, 2004, p. 41). 
In conclusion, following the logics of the analysis of the mentioned author, I will state that there is a real danger the political parties to become dependent on the corporate elites, which practice is often to hire one or another adviser as their lobbyists "quick order agents" who circle around their leadership cores like vultures. The other danger for the political parties in the post-democratic conditions is to fall into populism, when they are most often forced to make promises that are difficult or practically impossible to fulfill, such as "offering to reduce the tax burden", and so on. In this way, the parties doom the general elections to become a kind of "auctions" for tax reductions. In this race between the political parties, participating in such auctions, the election results can have fatal consequences for their future participation in the country's political life. Georgi Bliznashki gives a similar example with the introduction of the "flat tax" in 2007, when without consulting the people (voters) on the initiative of the Chairman of BSP Sergei Stanishev, who has led the government of the center-left "triple coalition", an attempt has been made to "perpetuate flat taxes in Bulgaria" (Bliznashki, Ganchev, 2012, p. XXI). In this article I have studied and analyzed the specifics related mainly to the development of the post-democracy, the relation between corporatism and democracy, as well as the changes in the role of the political parties and the institutions in the further strengthening of the post-democratic values and conditions for effective functioning of the post-democratic model. 
Димитар В. Димитров ${ }^{1}$

Бугарска академија наука

Софија (Бугарска)

\title{
ПРОМЕНЕ У УЛОЗИ ПОЛИТИЧКИХ ПАРТИЈА И ИНСТИТУЦИЈА У ПОСТДЕМОКРАТИЈИ
}

\author{
(Превоg In Extenso)
}

Сажетак: Рад расправља о променама у улози политичких партија и институција у модерним постдемократским друштвима. Његов циљ је да представи и анализира моделе успостављања и функционисања политичких партија и институција у постдемократској ери, њихов однос са савременом политичком стварношћу у Бугарској и земљама Европске заједнице. Главни приступ у студији и анализи проблема пред политичким партијама је социолошки у комбинацији са интердисциплинарним. Модели политичких партија и институција прате се и анализирају кроз призму модерне политичке науке. Наглашена је чињеница да постоји стварна опасност од тога да политичке партије постану зависне од корпоративних елита и широко распрострањеног политичког популизма. Наведени су стварни услови и приступи за превазилажење ових недостатака.

Кључне речи: политичке партије; политичке институције; модели политичких партија; лидерска језгра

Проблеми у вези са улогом и значајем политичких партија у постдемократији су предмет истраживања Колина Крауча у његовим публикацијама „Постдемократија” (2012) и „Неолиберализам и социјалдемократија - борба се наставља” (2019). У првој монографији аутор примењује оригинални приступ у дефинисању природе односа између партија и њиховог ширег бирачког тела. Колин Крауч примењује овај демократски модел истраживања, познат и као модел концентричних кругова, у проучавању партија. Каква је природа и специфичност овог модела? Он се углавном ослања на низ међусобно повезаних концентричних кругова помоћу којих би требало разјаснити сложени однос између појединачних партија и њиховог ширег гласачког тела. Препознатљиве одлике ових кругова су у томе што се њихова величина повећава и што су повезани на посебан начин. Према Колину Краучу,

„најмањи круг је језгро лидера и њихових саветника; затим следе представници у парламенту; после њих долазе активни чланови - људи који проводе много времена радећи за партију: представници локалне самоуправе, локални активисти, као и плаћени апартчици; следећи су обични чланови који врло мало раде за партију,

1 mitkodimitrov47@abv.bg 
али желе да буду симболично повезани са њом, па помажу у одређеним ситуацијама и редовно плаћају чланарину; затим долазе присталице или лојални гласачи који у суштини не раде ништа за партију осим што за њу гласају на изборима; на крају, највећи круг представља широко циљно гласачко тело које партија жели да убеди да гласају за њу" (Giddens, 1998, str. 80).

Ова дефиниција партијског модела са круговима различите величине и раста треба да постане уџбеник за оне амбициозне политичаре који, по напуштању руководећих положаја у некој партији или државној институцији, најчешће морају да предузму мере како би основали нову партију под њиховим личним вођством. Актуелни политички живот у Бугарској обилује оваквим примерима. Тако је господин Прванов, по истеку председничког мандата, основао нову партију (Алтернатива за бугарски препород) која није успела да се учврсти у политичком животу у земљи. Сличних примера има и међу осталим политичким силама у земљи. Социолошка анализа овог модела омогућава нам доношење неколико важних закључака.

Прво, у демократској партији, кругови су концентричне природе и одражавају смер кретања између учесника. На пример, лидере обично бирају активисти, које опет бирају чланови партије. Овде је специфична чињеница да су сами чланови партије представници различитих делова бирачког тела чије интересе партија покушава да заступа.

Друго, главна функција концентричних кругова, нарочито оних у средини, јесте стварање одговарајућих услова за изградњу чврстих односа политичких вођа и бирачког тела док прелазе разне нивое у партији. Према Колину Краучу, овај модел је нарочито важан за

„самоперцепцију радничких партија, за регионалне и сепаратистичке, али и демохришћанске и фашистичке партије. Оне се јављају ван парламента, као друштвени покрети, а затим развијају крило у парламенту. Међутим, у 20. веку су друштвени корени постали све важнији и за старе партије, проистекле из политичке елите, а касније, када су се неочекивано затекле у ери демократије, оне су пожуриле да смисле национални покрет" (Giddens, 1998, str. 80-81).

Такви примери могу се наћи у модерним европским елитама, као и у Бугарској. Тако, Покрет за права и слободе, „Атака”, Патриотски фронт и остали испуњавају тражене услове у Бугарској. Истичући ироничну природу појаве тих „партијских покрета”, Колин Крауч напомиње да је са успоном постдемократије, њихова претходна појава, односно модел покрета, постаје реалнији. Посебну пажњу треба обратити на закључак поменутог аутора да, као ни остали идеали, ни модел концентричних кругова, који строго утврђује правила кретања између ових кругова, практично никада није постојао, али је и даље упутно посматрати дати процес.

Правила игре у политици нису једина нити су створена да трају вечно. 3бог тога приликом проучавања ових процеса и проблема треба узети у обзир оне случајеве тензије када партијски лидери сумњају и не осећају стварну подршку „лојалног бирачког тела”. Политичким аналитичарима ово су изузетно важни сигнали да ће, уколико не буду узети у обзир, политички утицај партије опасти, те треба истражити разлоге за то. Овде у помоћ стижу социолози. Они, уз помоћ испитивања јавног мњења, могу да вођама одређене партије дају смернице о природи разлога и у којим правцима би их требало тражити. 
Настављајући анализу изазова које постдемократија поставља пред политичке партије, Колин Крауч упозорава на следећу чињеницу везано за последице концентричног модела. „Даља промена била је снажно ширење кругова саветника и лобиста око вођа. Иако се могу разликовати три групе - вође, саветници и лобисти - у пракси се људи крећу између тих положаја и заједно стварају политику као посебно занимање” (Giddens, 1998, str. 82). Са појавом ове три групе мења се само језгро партије, као и други партијски кругови који добијају облик елипсе. Посебно место у структури партије заузимају „чисти професионалци”, који не морају да буду чланови партије, али су ангажовани за обављање строго дефинисаног посла. Циљеви ових група обично се преклапају са циљевима лобиста који такође раде за одређене компаније и који имају одређене интересе у државним пословима. Сви они као крајњи циљ имају успостављање ближег контакта са политичарима. У том зачараном кругу свакако има извесних услова за скандале и укљученост у шеме корупције. Због тога су све партије рањиве и могу да претрпе последице тих повремено фаталних сукоба и тензија. Као што Колин Крауч напомиње, „нарочито у периоду дубоких класних промена, оне могу постати немогуће за управљање... А резултат ангажовања стручњака био је то што се структура руководства померила још даље од партијских кругова према елипси" (Giddens, 1998, str. 83-84). У ствари, ова елипса ствара нове услове за интеракцију са партијским вођама. Стручност и знање елипсе много је драгоценије и корисније од „аматерског ентузијазма” партијских активиста. На тај начин ћемо, ако верујемо садашњим трендовима, видети ново лице партије 21. века.

„Та партија, каже Колин Крауч, обухватиће самореплицирајућу домаћу елиту, удаљену од масовних покрета у својој основи, али у потпуности угнежђену у неколико корпорација које подуговарају услуге за проучавање јавног мњења... Партија - када је на власти - фаворизује компаније које заузврат траже политички утицај" (Giddens, 1998, str. 84).

На сличан начин, основана је партија десног крила по имену Forza Italia која je, после скандала са корупцијом у Демохришћанској и Социјалистичкој партији почетком 90-их година 20. века, прокрчила предузетнику Силвију Берлусконију пут ка моћи. Овај тип партије је својеврсна мрежа компанија, а њен успех углавном почива на личним квалитетима њеног лидера. Такве партије имају огромну потребу за новцем, а изборне кампање постају све скупље. У тим условима расте потреба за богатим спонзорима, док су све ограниченије могућности за прикупљање средстава на неки други легалан начин. Следи „царство хаоса” у којем се већина политичких партија окреће коруптивним радњама које дискредитују слику о њима, а када оне то схвате, већ су изгубиле подршку својих чланова и савеза и постале у великој мери зависне од корпорација. Према Колину Краучу, јавља се чудан парадокс у којем нова елипса, која обухвата кретање од вођства ка саветницима и спољним лобистима, садржи елементе из предемократског и постдемократског периода (Giddens, 1998, str. 86-87). Овако се граде имиџ и структура постдемократских политичких партија.

Овде ћу се усредсредити углавном на неке од мојих анализа и закључака о питањима о партијама која су постављена у мојој књизи „Моћ и политика” (2017). Један од циљева те студије био је да се примени социолошки приступ како би се партија сагледала као политичка организација у контексту целокупног демократског процеса. 
Остваривање овог циља захтевало је праћење историјских услова и периода током којег су основане политичке партије. У том смислу, моје проучавање отпочело је разматрањем резултата студија и анализа Макса Вебера из његове публикације „Научник и политичар” (Weber, 1993). Темељно анализирајући услове у којима се формирају „професионални политичари”, Макс Вебер истиче разлоге њиховог постојања и напомиње: „Човек се може бавити 'политиком', тј. покушати да утиче на поделу власти између политичких формација и унутар њих, само у појединим случајеви или као политичар којем је ово споредно или главно занимање” (Weber, 1993, str. 52). Објашњавајући како се професионални политичари разликују од обичних гласача, Макс Вебер закључује да постоје само два начина на који ће човек претворити политику у своју професију: „Он треба да живи према политици или да живи за политику”. При томе, оно прво не искључује друго (Weber, 1993, str. 53). Ово је типична дефиниција која објашњава специфичности времена у којем је живео Макс Вебер, односно времена пре појаве партија у западној политици. Његова размишљања и анализе дају одговоре на питања: Ко су људи заинтересовани за политички живот? Како се врши селекција кандидата за изборе? Како се добијају гласови? Ти одговори делују релевантно чак и данас, са ове временске дистанце у односу на период када је живео Макс Вебер. Са методолошког становишта, позвао сам се на бугарске социологе који поклањају посебну пажњу откривању природе партија у данашњој репрезентативној демократији. У студији Георгија Фотева, откривање природе партија повезано је са задатком модерне демократије од које се, по његовом мишљењу, захтева

„да успостави друштвени поредак на основу неслагања, а та неслагања створила би невероватну какофонију, почела би да доводе до незамисливог хаоса без механизама, правећи пут за друштвени поредак и одржавање поретка, укључујући и његову промену и развој на демократски начин” (Fotev, 2001, str. 323).

3бог упадљивих неслагања у мишљењима, формира се група оних који су једногласни у погледу одређених политичких питања, па се уједињују у политичку партију. Према Фотеву, ова партија је „специфично удружење” у демократском друштву. Друго поређење које аутор користи за партију јесте „лабораторија”, тј. „школа партијско-политичког живота”, где партијски активиста стиче посебно политичко знање и политичку компетентност, може да развије своје таленте као политички вођа и, ако буде примећен прво међу члановима партије и докаже своје квалитете и њима и политичком друштву, он може да оствари успешну партијску и политичку каријеру (Fotev, 2001, str. 325).

Минчо Семов има другачији поглед на природу и начине организовања партија. Он разлоге за појаву политичких организација тражи у самој природи и суштини јавног живота организованог унутар државе. Овај аутор скреће пажњу на једну значајну чињеницу, односно на постојање центара моћи који имају одређени извор средстава да утичу на политички живот у друштву. Оснивање политичке партије као организације повезано је са јасно постављеним циљем, а то је освајање центара моћи у друштву. Ова тврдња коју заговара Минчо Семов налази се у домену тезе о моћи коју је дао Макс Вебер, тј. да се партија формира како би учествовала у вршењу власти. Свака друга теза која пориче овај циљ оснивања неке партије био би израз хипокритичног политиканства и популизма. Минчо Семов сматра да је 
„партија организовано удружење људи са заједничким интересима, идејама и погледима. Класичан циљ је те интересе, идеје и погледе наметнути читавој заједници (друштву, држави) преузимањем власти. Привремени циљ политичке партије може бити очување одређених вредности, чување и преношење „ватре” итд. (Semov, 2000, str. 387).

Расправа о проблемима у вези са природом, структуром и месту политичких партија у политичком систему друштва води се у социолошкој литератури све до данас. Завршићу ову расправу сопственом тезом о природи политичке партије, њеној структури и функцијама. Пре него што дефинишем политичку партију, даћу два појашњења - прво, да партију сматрам средством учешћа у власти и друго, да је партија један од „главних инструмената политичког надметања” (Jacques Chevallier). У том смислу, на моју дефиницију „партије” утицале су тезе поменутог аутора.

По мом мишљењу, политичка партија је дволично политичко (а не економско) предузеће, нешто попут „бога Јануса са два лица”. Једно лице партије окренуто је према унутрашњој страни, односно члановима који представљају делове друштвених група и заједница са заједничким интересима и циљевима повезаним са учешћем њихове партије у власти - они су добровољно прихватили и признали право партијског руководства да контролише њихове радње. Друго лице окренуто је ка спољашњој страни, тј. представницима цивилног друштва, синдиката и осталих организација и политичких партија који имају исти циљ - учешће у власти и подели користи. Прво лице, окренуто ка унутра, обезбеђује дисциплину и контролу над међусобним односима између разних нивоа хијерархије, док друго лице, окренуто ка спољашњој страни, одређује сарадњу са осталим политичким партијама, цивилним друштвом, синдикатима и деловима других организација. Главна брига овог лица јесте са киме, када и како образовати коалиције и остале уговорне односе како би се добило учешће у власти. Моја дефиниција постављена је као методолошки услов у овој студији, где ћу се у кратким цртама фокусирати на расправу о функцијама политичких партија. Бугарски и страни аутори из области политичких наука дефинитивно активније учествују у овој расправи. У том погледу, навешћу и гледиште већ поменутог француског научника Жака Шевалијеа. Оригиналност његовог гледишта је у томе што у монографији „Политичке институције” (2010), анализирајући функције политичких партија, креће од тезе да су функције партија двосмислене, истовремено отворене и скривене. Када је реч о отвореним функцијама, он говори о три типа:

„формирање јавног мњења представљањем низа мишљења гласачима (програмска функција) и сталним оживљавањем јавне расправе, регрутовање политичког особља (селекциона функција) именовањем кандидата за изборе и одговорне руководеће позиције; координација и контрола активности изабраних кандидата (функција уоквиравања) кроз парламентарне групе. Али партије, наставља он, такође имају скривене функције као што су: политичка социјализација (политичко образовање и структурирање гласова), друштвена интеграција (сугерисање уверења) и друштвена мобилност (функција „трибуна” која од њих захтева да обезбеде заштиту и заступање одређених друштвених слојева који су маргинализовани)" (Chevallier, 2010, str. 107).

Поређење теза претходно поменутих социолога и политиколога означено је као „преклапање” у дефиницији политичких партија и њихових функција. Узимајући у 
обзир ову чињеницу, политиколог Георги Манолов дефинише следеће „најзначајније” функције партија. Он их дели у

„две кључне групе: репрезентативне - функције у односу на цивилно друштво (артикулисање и агрегација јавних интереса; институционализација друштвених конфликата, однос цивилног друштва и државе; формирање јавног мњења...) и институционалне - функције у односу на државну администрацију (има их укупно 7)” (Manolov, 2016, str. 244).

О тези овог аутора о функцијама партија детаљније се говори у мојој монографији „Моћ и политика” (2017), па ћу овде само констатовати да делим ауторово мишљење о стабилизујућој функцији партија, захваљујући њиховој способности да институционализују друштвене конфликте. Са становишта моје дефиниције партије, додаћу само да, поред екстерних конфликата повезаних са грађанским и осталим препрекама, партија такође може да регулише унутрашње конфликте који се јављају између разних нивоа хијерархије, разних група чланова који се не слажу са одређеним одлукама руководства о спровођењу организационих и структурних реформи, са правилима о учешћу у парламентарним групама, правом на учешће на парламентарним изборима и друго. Већина поменутих врста сукоба појавила се током пленума Бугарске социјалистичке партије поводом избора новог председника партије. Наставља се жестока борба између старих партијских чланова који су имали извесне руководеће положаје, попут вође ове групе, вође партијске организације Пловдива и његових осталих присталица, и клике садашњег партијског вође. Резултат ове борбе биће познат у јесен 2020. године, када ће се одржати партијски конгрес. Постојање извесних сукоба, као што су већ поменути сукоби око обнављања партијског вођства, није тако опасно и може се дефинисати и као мање штетно за партију. Наиме, моја теза је да сукоби ове врсте делују на здрав начин и сведоче о опоравку партијског организма, под условом да се они систематично прате и да се траже начини за превазилажење разлика проузрокованих конфликтима.

У закључку ћу напоменути да број и природа функција политичке партије зависе од типа саме партије. У том смислу, сматрам да је развој типологије партија важан за дубље проучавање природе и карактера политичких партија. У мојој већ поменутој студији „Моћ и политика” (2017) анализирао сам постојеће типологије у бугарској и страној литератури, па овде нећу детаљно дискутовати о проблемима у развоју датих типологија партија.

Значајно место у мојој студији заузимају политичке институције као један од главних елемената политичког система моћи у условима постдемократије и у целокупном политичком процесу. Термин „институција”, као што каже Жак Шевалије, настао је у Француској 1954. године у вези са реформом правног образовања у уџбеницима из уставног права и представља један од успешних покушаја политичких наука у Француској да се створе услови за „прелажење граница” правног приступа.

Наредне 1955. године су предавања Жоржа Бирдоа и Мориса Дивержеа доживела огромне промене, потврђујући потребу да се узме у обзир право на постојање „политичких институција”. На овај начин су створени услови и прави предуслови, као што пише Жак Шевалије, „да професори уставног права не прате само прописе и тела која обезбеђује устав, већ и да буду заинтересовани за политичку стварност, 
услове примене уставних норми од стране група које утичу на вршење политичке моћи, нарочито партија" (Chevalier, 2010, str. 9). Морис Диверже, који је 1951. објавио књигу „Политичке партије”, такође је у одређеној мери заслужан за легитимизацију термина „политичке институције”. Његова студија потврђује термин „партијски систем”, који се све више повезује са политичким режимима. Међутим, Жак Шевалије истиче да све од њеног увођења, фраза „политичке институције” садржи одређену двозначност. Са развојем политичких наука, термин „политичке институције” заузео је заслужено место у истраживањима политичких наука и, као што је напоменуо овај аутор, следећи логику институционализације „политичких институција”, потврђује идеју да су политичке институције само варијанта друштвених институција (Dimitrov, 2017, str. 91). У бугарској социолошкој литератури треба обратити пажњу на дефиницију друштвене институције коју је дао Стојан Михаилов у својој монографији „Социолошки систем” (2010). Према њему:

„Друштвена институција образује се да би организовала, каналисала, усмерила и контролисала активности људи. Она прати поделу јавног рада. Диференцира се према релативно засебним врстама људске активности. Због тога постоје разни типови друштвених институција - производне, управљачке, образовне, научне, комерцијалне, спортске, црквене, комуникационе, политичке итд.” (Mihailov, 2010, str. 70).

Другим речима, аутор овде наглашава чињеницу да свака институција припада једној од главних сфера друштва или његовом главном подручју као саставном делу социолошког система друштва. Поменути француски истраживач Жак Шевалије истиче да су студије о политичким институцијама у великој мери већ упознате са чињеницом да су те институције у суштини својеврсна „потпорна структура” поретка у друштву. Због тога, како наводи Жак Шевалије, „институције треба схватити као друштвене чињенице које су трајно урезане у време, личе на 'објективну' или ,природну“ стварност и као такве постоје кроз појединце” (Chevallier, 2010, str. 34).

У нашој политиколошкој литератури постоје две основне дефиниције политичких институција које су дали домаћи аутори. Према Антонију Тодорову, „политичке институције требало би сматрати системом прописа и норми који обезбеђује одређени друштвени и политички поредак” (Todorov, 2012, str. 78). Али, како овај аутор истиче, у свакодневном животу постоје институције које обухватају државне власти и њихове јединице као што су влада, парламент, председник, суд, полиција, војска и тако даље. Друга дефиниција политичких институција, коју је дао политиколог Георги Карасимеонов, гласи: „У ширем смислу, институције обухватају такозване посредничке институције између грађана и државе, као што су политичке партије и остале организације цивилног друштва. Понекад се те институције називају грађанским институцијама" (Todorov, 2012, str. 79). Важно је то што у проучавању политичких институција, како нас подсећа Минчо Семов, њихов јавни карактер треба разликовати од приватног живота.

У мојој монографији „Моћ и политика” (2017) посветио сам посебну пажњу другим типовима политичких институција као што су: држава, парламент, влада, правосуђе, које представљају политичку везу између политичког система и његових институција у оквиру целокупног политичког процеса. Због тога овде нећу говорити о њиховој природи и начину функционисања, већ пре о неким специфичностима 
политичких институција као што је држава. Према фигуративном изразу Колина Крауча, у контексту постдемократије, „држава постаје својеврсни 'институционални идиот чији су поступци очекивани и неутрализовани од стране свезнајућих идеолога тржишне економије” (Crouch, 2004, str. 41).

У закључку, пратећи логику анализе овог аутора, констатоваћу да постоји стварна опасност да ће политичке партије постати зависне од корпоративне елите, које често практикују да ангажују неке саветнике као своје лобисте који поступају као „брзо наручени агенти” и круже око лидерских језгра попут лешинара. Друга опасност за политичке партије у постдемократским условима јесте западање у популизам, где су политичке партије најчешће присиљене да дају обећања која је тешко или готово немогуће испунити, на пример „понуђено смањивање пореског оптерећења” итд. На тај начин партије доводе до тога да општи избори постану нека врста „аукција" за смањење пореза. Услед те трке између политичких партија које се надмећу на аукцијама, изборни резултати имају фаталне последице за будуће учешће тих партија у политичком животу земље. Георги Близнашки даје сличан пример - увођење „паушалног пореза” 2007. године, када је, без претходних консултација са народом (гласачима) о иницијативи председника Бугарске социјалистичке партије Сергеја Станишева, који је предводио владу „тројне коалиције” левог центра, направљен покушај да се „паушални порези трајно усвоје у Бугарској” (Bliznashki, Ganchev, 2012, str. XXI). У овом раду проучио сам и анализирао углавном специфичности у вези са развојем постдемократије, односом између корпоративизма и демократије, као и промене у улози политичких партија и институција у даљем јачању постдемократских вредности и услова за ефикасно функционисање постдемократског модела.

\section{REFERENCES / ЛИTEPATУPA:}

Bliznashki, G., Gauche, G. (2012). The Challenges of Post-Democracy. (Introduction). In: Crouch, C. (ed.) Post-democracy. University Publishing House "St. Kliment Ohridski" [In Bulgarian]

Chevallier, J. (2010). Institutions Politiques. University Publishing House "St. Kliment Ohridski” [In Bulgarian]

Crouch, C. (2004). Post-democracy. London.

Crouch, C. (2012). Post-democracy. University Publishing House "St. Kliment Ohridski” [In Bulgarian]

Crouch, C. (2019). Neoliberalism and Social Democracy - the Fight Continues. University Publishing House "St. Kliment Ohridski" [In Bulgarian]

Dimitrov, D. (2017). Power and Politics. "VUSI" Publishing House [In Bulgarian]

Fotev, G. (2001). Limits of Politics. "LiK" [In Bulgarian]

Giddens, A. (1998). The Third Way. "Prozorets" [In Bulgarian]

Manolov, G. (2016). Political Management. Plovdiv: "VUSI” [In Bulgarian]

Mihailov, S. (2010). Sociological System. "M-8-M" [In Bulgarian]

Semov, M. (2000). Theory of Politics. "Sophie-R" [In Bulgarian]

Todorov, A. (2012). Elements of the Politics. NBU [In Bulgarian]

Weber, M. (1993). The Scientist and the Politician. "Micro-Print" [In Bulgarian] 